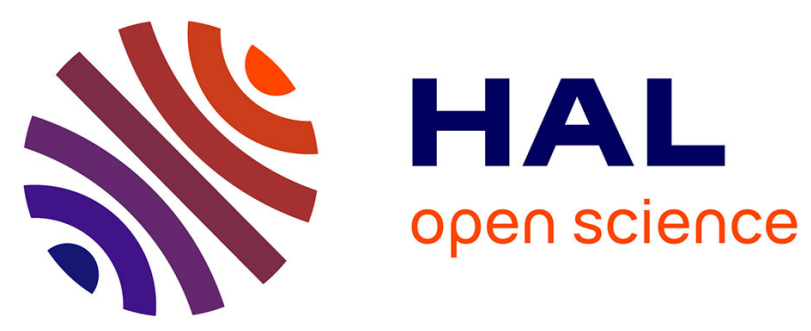

\title{
Towards an understanding of light activation processes in titanium oxide based inverted organic solar cells
}

Sylvain Chambon, Elodie Destouesse, Bertrand Pavageau, Lionel Hirsch, Guillaume Wantz

\section{- To cite this version:}

Sylvain Chambon, Elodie Destouesse, Bertrand Pavageau, Lionel Hirsch, Guillaume Wantz. Towards an understanding of light activation processes in titanium oxide based inverted organic solar cells. Journal of Applied Physics, 2012, 112 (9), pp.094503. 10.1063/1.4764026 . hal-00780596

\section{HAL Id: hal-00780596 https://hal.science/hal-00780596}

Submitted on 24 Jan 2013

HAL is a multi-disciplinary open access archive for the deposit and dissemination of scientific research documents, whether they are published or not. The documents may come from teaching and research institutions in France or abroad, or from public or private research centers.
L'archive ouverte pluridisciplinaire HAL, est destinée au dépôt et à la diffusion de documents scientifiques de niveau recherche, publiés ou non, émanant des établissements d'enseignement et de recherche français ou étrangers, des laboratoires publics ou privés. 


\section{AIP Applied Physics}

\section{Towards an understanding of light activation processes in titanium oxide based inverted organic solar cells}

S. Chambon, E. Destouesse, B. Pavageau, L. Hirsch, and G. Wantz

Citation: J. Appl. Phys. 112, 094503 (2012); doi: 10.1063/1.4764026

View online: http://dx.doi.org/10.1063/1.4764026

View Table of Contents: http://jap.aip.org/resource/1/JAPIAU/v112/i9

Published by the American Institute of Physics.

\section{Related Articles}

Power losses in bilayer inverted small molecule organic solar cells Appl. Phys. Lett. 101, 233903 (2012)

Thin-film encapsulation of inverted indium-tin-oxide-free polymer solar cells by atomic layer deposition with improvement on stability and efficiency

Appl. Phys. Lett. 101, 233902 (2012)

The roles of metallic rectangular-grating and planar anodes in the photocarrier generation and transport of organic solar cells

Appl. Phys. Lett. 101, 223302 (2012)

The roles of metallic rectangular-grating and planar anodes in the photocarrier generation and transport of organic solar cells

APL: Org. Electron. Photonics 5, 255 (2012)

Towards the development of a virtual organic solar cell: An experimental and dynamic Monte Carlo study of the role of charge blocking layers and active layer thickness

Appl. Phys. Lett. 101, 193306 (2012)

\section{Additional information on J. Appl. Phys.}

Journal Homepage: http://jap.aip.org/

Journal Information: http://jap.aip.org/about/about_the_journal

Top downloads: http://jap.aip.org/features/most_downloaded

Information for Authors: http://jap.aip.org/authors

\section{ADVERTISEMENT}

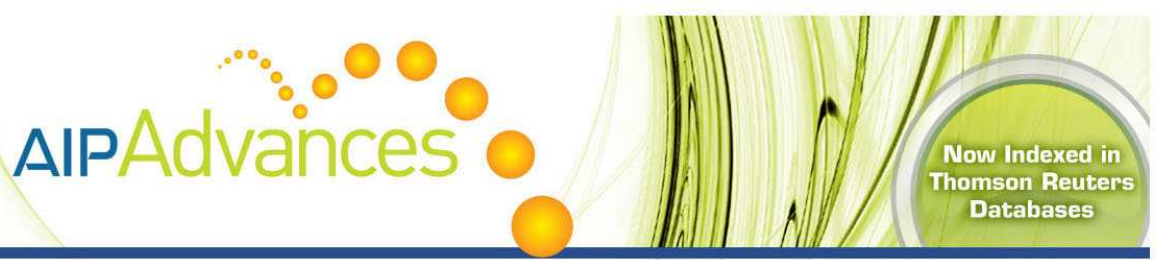

\section{Explore AIP's open access journal: - Rapid publication \\ - Article-level metrics \\ Post-publication rating and commenting}




\title{
Towards an understanding of light activation processes in titanium oxide based inverted organic solar cells
}

\author{
S. Chambon, ${ }^{1}$ E. Destouesse, ${ }^{1}$ B. Pavageau, ${ }^{2}$ L. Hirsch, ${ }^{1}$ and G. Wantz ${ }^{1, a)}$ \\ ${ }^{1}$ Univ. Bordeaux, IMS, UMR 5218, F-33400 Talence, France and CNRS, IMS, UMR 5218, F-33400 Talence, \\ France \\ ${ }^{2}$ Univ. Bordeaux, LOF, UMR 5258, F-33600 Pessac, France; CNRS, LOF, UMR 5258, F-33600 Pessac, \\ France; and RHODIA, LOF, UMR 5258, F-33600 Pessac, France
}

(Received 14 June 2012; accepted 9 October 2012; published online 5 November 2012)

\begin{abstract}
The light activation phenomenon in inverted P3HT:PCBM bulk heterojunction organic solar cells based on titanium oxide sublayer $\left(\mathrm{TiO}_{\mathrm{x}}\right)$ is characterized by fast acquisition of current-voltage $(\mathrm{J}-\mathrm{V})$ curves under light bias as function of time. $\mathrm{TiO}_{\mathrm{x}}$ layers were thermally treated under inert atmosphere at different temperatures prior active layer deposition and for every device an activation time was extracted. It is shown that the higher the $\mathrm{TiO}_{\mathrm{x}}$ annealing temperature, the faster the activation. The improvement of the overall device performances is also observed for devices with $\mathrm{TiO}_{\mathrm{x}}$ layers baked above $100^{\circ} \mathrm{C}$. The evolution of the characteristic of the organic semiconductors (OSC) device, from dielectric to diode, is attributed to the increase of $\mathrm{TiO}_{x}$ conductivity by three orders of magnitude upon white light illumination. Additionally, devices based on baked $\mathrm{TiO}_{\mathrm{x}}$ present higher conductivity than those based on unbaked $\mathrm{TiO}_{\mathrm{x}}$ which would explain the gain in performances and the short activation time of the OSC. In order to understand the origin of the phenomenon, deactivation experiments were also performed under different conditions on OSC. The deactivation process was shown to be thermally dependent and fully reversible under inert atmosphere, which suggest that deep traps are responsible for the activation phenomenon. An optimal annealing temperature was found at $120^{\circ} \mathrm{C}$ and gives a reasonable short activation time of approximately $1 \mathrm{~min}$ and photo conversion efficiency up to 4\%. (C) 2012 American Institute of Physics. [http://dx.doi.org/10.1063/1.4764026]
\end{abstract}

\section{INTRODUCTION}

Polymer photovoltaic solar cells (PSC) have been the subject of increasing attention around the world for the last 20 years as a potential source of renewable energy. PSC offer multiple advantages such as low production costs, reduced weight, potential flexibility, and power conversion efficiencies (PCE) approaching values of amorphous silicon industry. ${ }^{1}$ Since 2005, so-called inverted PSC have been developed which exhibit improved air stability compared to conventional direct structures. ${ }^{2-5}$ In an inverted PSC, electrons are collected by the indium tin oxide (ITO) bottom electrode through transparent electron selective layers, whereas holes are collected from the evaporated top electrode, generally across a thin film of hole selective layer such as molybdenum oxide $\left(\mathrm{MoO}_{3}\right)$ or poly(3,4-ethylenedioxythiophene) doped with poly(4-styrenesulfonate) (PEDOT-PSS). The top electrode is generally made of silver, since air exposure leads to the formation of silver oxide; the latter exhibits a higher work function thus enhancing hole collection. ${ }^{6}$ Several materials such as calcium, ${ }^{7,8}$ titanium oxide $\left(\mathrm{TiO}_{\mathrm{x}}\right),{ }^{9,10}$ zinc oxide $(\mathrm{ZnO}),{ }^{11-13}$ cesium carbonate $\left(\mathrm{Cs}_{2} \mathrm{CO}_{3}\right),{ }^{14,15}$ or aluminum-doped zinc oxide ${ }^{9}$ have been introduced as transparent electron-selective layers. S-shape current-voltage (IV) curves or inflection points in direct solar cells have been observed and reported in various articles. ${ }^{16,17}$ These authors attributed this phenomenon to the presence of

\footnotetext{
a) Author to whom correspondence should be addressed; Electronic mail: guillaume.wantz@ims-bordeaux.fr.
}

strong interface dipoles or spaces charges due to a reduced majority surface recombination velocity. Similar inflection points can be observed in inverted solar cells build on $\mathrm{ZnO}$ and $\mathrm{TiOx}$ layers. In many cases, inverted solar cells built using $\mathrm{TiO}_{\mathrm{x}}$ or $\mathrm{ZnO}$ present similar S-shaped IV characteristics which can be suppressed under continuous white light illumination. Such activation of inverted solar cells has been reported in a few articles for $\mathrm{TiO}_{\mathrm{x}}$ based ${ }^{18-21}$ as well as in $\mathrm{ZnO}$ based devices. ${ }^{22-26}$ The commonly accepted explanation for $\mathrm{ZnO}$ activation is that adsorbed molecular oxygen acts as an electron trap and causes bending of the titania band diagram, therefore forming a barrier against the extraction of electrons. Upon UV illumination (part of the white light illumination of a sunlight or solar simulator), this adsorbed species desorbs and the charge extraction is enhanced, explaining the improvement of the fill factor. ${ }^{22-26}$ However, in the case of $\mathrm{TiO}_{\mathrm{x}}$, the origin of the phenomenon is still under debate. While some groups claim that activation comes from adsorbed molecular oxygen (as for $\mathrm{ZnO}$ ), ${ }^{21,27} \mathrm{Kim}$ et al. support the hypothesis that shallow charge carrier traps are present in between the valence band and the conduction band of $\mathrm{TiO}_{\mathrm{x}}$, which are filled upon UV irradiation of the $\mathrm{TiO}_{\mathrm{x}}$ layer, therefore improving its series resistance and photo-conductivity. ${ }^{20}$ Whatever the physical origin, improvement of the fill factor results in the disappearance of the insulating zone at one interface.

In this article, we attempt to give some insights on the light activation phenomenon. The light activation duration is studied via fast current-voltage measurements as a function 
of thermal treatment of the oxide under inert atmosphere prior to the deposition of the bulk heterojunction. For every sample, the evolution of various photovoltaic parameters $\left(\mathrm{J}_{\mathrm{sc}}, \mathrm{V}_{\mathrm{oc}}, \mathrm{FF}, \mathrm{PCE}\right)$ as a function of the irradiation time is plotted in order to extract a corresponding rising time. Fully activated devices are submitted to different storage conditions in order to study the deactivation of the device and understand the origin of the traps. Pure $\mathrm{TiO}_{\mathrm{x}}$-based devices were also fabricated in order to study the influence of the thermal treatment on the conductivity of the $\mathrm{TiO}_{\mathrm{x}}$ layer.

\section{MATERIALS AND METHODS}

The bulk heterojunction used in this study is based on a well-known couple of materials: poly(3-hexylthiophene) (P3HT) and 1-(3-methoxycarbonyl)propyl-1-phenyl[6,6] $\mathrm{C}_{61}$ (PCBM), which has been extensively studied in the last decade. ${ }^{28}$ Inverted solar cells have been fabricated with the structure Glass/ITO/TiO $/ \mathrm{P} 3 \mathrm{HT}: \mathrm{PCBM} / \mathrm{MoO}_{3} / \mathrm{Ag}$ using standard procedures. $15 \times 15 \mathrm{~mm}^{2}$ ITO-coated glass sheets $\left(10 \Omega^{2}\right.$, Kintec) are successively cleaned in acetone, ethanol, and isopropanol in an ultrasonic bath and exposed to UV-ozone for $20 \mathrm{~min}$. Titanium oxide is prepared as followed: Titanium (IV) isopropoxide (TIPT, Aldrich, 99.999\%) is diluted in absolute ethanol at a concentration of $0.05 \mathrm{M}$, to which $\mathrm{HCl}$ is added in order to have a water to TIPT molar ratio (rw) of 0.82 and a $p \mathrm{H}$ of $1.9 .^{29}$ The precursor solution is stirred for $72 \mathrm{~h}$ at room temperature. $40 \mu \mathrm{l}$ of $\mathrm{TiO}_{\mathrm{x}}$ solution is spincoated on the substrate in air (ambient atmosphere) at $1000 \mathrm{rpm}$ for $60 \mathrm{~s}$ and kept in air at room temperature for $2 \mathrm{~h}$. Subsequently, the substrates were transferred to a nitrogen-filled glovebox $\left(\mathrm{O}_{2}\right.$ and $\mathrm{H}_{2} \mathrm{O}$ $<0.1 \mathrm{ppm}$ ). Starting from this point, the rest of the fabrication process and all the $\mathrm{I}(\mathrm{V})$ characterizations are carried out under inert atmosphere. $\mathrm{TiO}_{\mathrm{x}}$ coated ITO sheets were then thermally treated at various temperatures from $80^{\circ} \mathrm{C}$ to $180^{\circ} \mathrm{C}$ for 10 min on temperature-controlled hot plate. The $\mathrm{TiO}_{\mathrm{x}}$ thickness was measured to be $15 \pm 5 \mathrm{~nm}$ using a Tencor $I Q$ profilometer. P3HT (Plexcore OS2100) and PCBM (99.5\%) were supplied from Plextronics and Solaris-Chem Inc., respectively, and used as received. Solutions were prepared in o-dichlorobenzene, at a $1: 1$ weight ratio and a concentration of $20 \mathrm{mg} / \mathrm{ml}$. Solutions were first stirred at $90^{\circ} \mathrm{C}$ for $10 \mathrm{~min}$ and subsequently at $50^{\circ} \mathrm{C}$ for $24 \mathrm{~h}$. P3HT:PCBM was spincoated at $1000 \mathrm{rpm}$ during $25 \mathrm{~s}$. Instantly after spin-coating, the substrates were individually placed in small closed petri dishes overnight at room temperature for solvent annealing. Solvent annealing is a well-known technique to promote the phase segregation of bulkheterojunction materials by keeping the layers under a saturated solvent atmosphere. ${ }^{30}$ It is important to mention that no thermal annealing of BHJ was performed in this study, in order to increase the effect of temperature on $\mathrm{TiO}_{\mathrm{x}}$ only. The resulting P3HT:PCBM thickness was $240 \pm 10 \mathrm{~nm}$. Both the solvent annealing procedure and the spincoating time coupled to solution concentration, i.e., active layer thickness, were optimized. $8 \mathrm{~nm}$-thick $\mathrm{MoO}_{3}$ (Serac) followed by $100 \mathrm{~nm}$-thick silver electrodes were successively thermally evaporated under a secondary vacuum $\left(10^{-6} \mathrm{mbar}\right)$ onto the P3HT:PCBM layer through a shadow mask to define a $8.6 \mathrm{~mm}^{2}$ active area. Experiments were repeated on 8 individual cells to evaluate the standard deviation. The devices were characterized using a K.H.S. SolarCelltest- 575 solar simulator with AM1.5 G filters set at 100 $\mathrm{mW} / \mathrm{cm}^{2}$ with a calibrated radiometer (IL 1400BL). Labview controlled Keithley 2400 SMU enabled the measurement of current density-voltage (J-V) curves every $4 \mathrm{~s}$ to observe any eventual curve modification during light exposure.

For the TiOx conductivity study, specific devices were fabricated using the following procedure. $15 \times 15 \mathrm{~mm}^{2}$ glass sheets are successively cleaned in acetone, ethanol, and isopropanol in an ultrasonic bath and exposed to UV-ozone for $20 \mathrm{~min}$. Using the same titanium oxide precursor solution, a TiOx precursor layer is deposited by spin-coating (1000 rpm, $60 \mathrm{~s}$ ) onto the glass sheets. After $2 \mathrm{~h}$ of conversion under air, the samples were put under an inert $\left(\mathrm{N}_{2}\right)$ atmosphere $\left(\left[\mathrm{O}_{2}\right]\right.$ and $\left[\mathrm{H}_{2} \mathrm{O}\right]<0.1 \mathrm{ppm}$ ) and thermally treated at various temperatures from $80^{\circ} \mathrm{C}$ to $180^{\circ} \mathrm{C}$ for $10 \mathrm{~min}$. Aluminum top contacts were then deposited by thermal evaporation in order to define the channel length and width, $50 \mu \mathrm{m}$ and $2.5 \mathrm{~mm}$, respectively. The $\mathrm{I}(\mathrm{V})$ characteristics of this devices, in the dark and under illumination, were recorded using a Keithley 4200 SMU and the same solar simulator was used for solar cell characterization.

\section{RESULTS AND DISCUSSION}

\section{A. Activation phenomenon}

Figure 1(a) shows successive J-V curves of an inverted cell with untreated $\mathrm{TiO}_{\mathrm{x}}$ measured under an inert
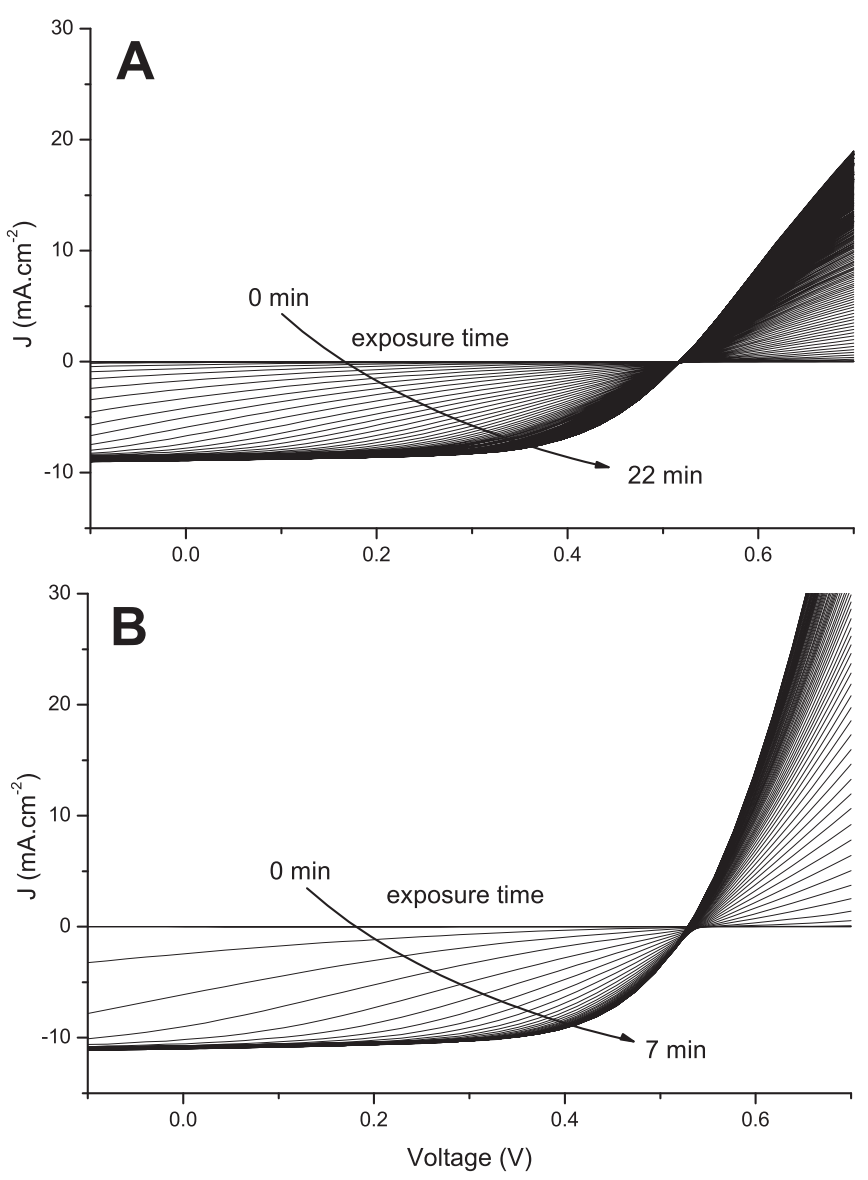

FIG. 1. Current density—voltage curves of solar cells upon light activation. Time delay between curves is $4 \mathrm{~s}$. (a) Devices with pristine $\mathrm{TiO}_{\mathrm{x}}$ and (b) devices with $\mathrm{TiO}_{\mathrm{x}}$ pre-treated at $180^{\circ} \mathrm{C}$. 


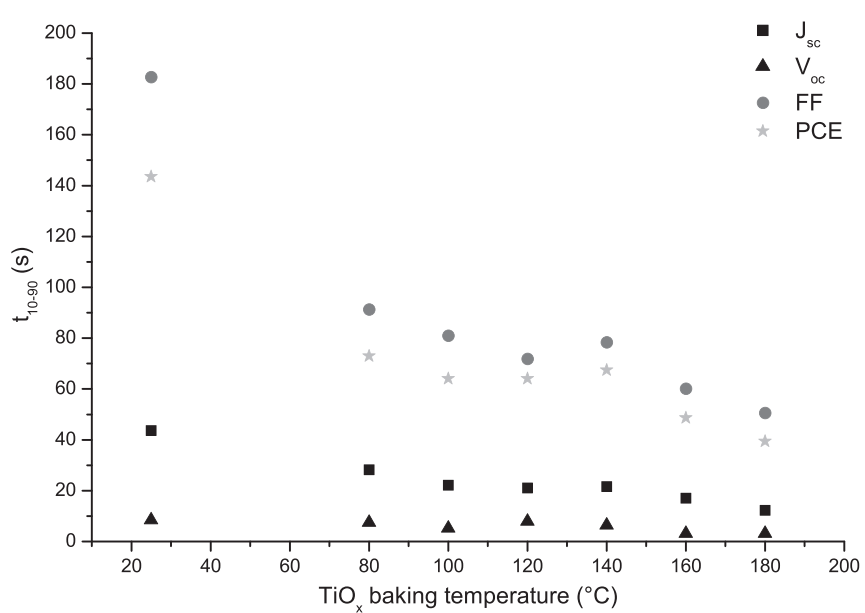

FIG. 2. Evolution of the rising time $\left(\mathrm{t}_{10-90}\right)$ for $\mathrm{J}_{\mathrm{sc}}, \mathrm{V}_{\mathrm{oc}}, \mathrm{FF}$ and PCE as a function of the baking temperature of $\mathrm{TiO}_{\mathrm{x}}$ layer.

atmosphere. The first J-V curve does not show any significant rectification behavior under illumination nor in the dark. Thus, neither photocurrent nor photovoltage is initially measured. Overtime, short-circuit current $\left(\mathrm{J}_{\mathrm{sc}}\right)$ slowly appears and increases up to reasonable values of $8.7 \mathrm{~mA} / \mathrm{cm}^{2}$ after $22 \mathrm{~min}$ of continuous light activation. These $\mathrm{J}-\mathrm{V}$ curves suggest that the fill factor (FF) is strongly dependent on the light soaking while the open-circuit voltage $\left(\mathrm{V}_{\mathrm{oc}}\right)$ and $\mathrm{J}_{\mathrm{sc}}$ are less affected. The power conversion efficiency (PCE) of untreated $\mathrm{TiO}_{\mathrm{x}}$ cells increases up to $2.8 \%$. Figure 1(b) shows the same $\mathrm{J}-\mathrm{V}$ curves recorded on cells with thermally treated $\mathrm{TiO}_{\mathrm{x}}$ at $180^{\circ} \mathrm{C}$ during $10 \mathrm{~min}$ under an inert atmosphere prior to the deposition of the bulk heterojunction. With the same time-lapse of $4 \mathrm{~s}$ between $\mathrm{J}-\mathrm{V}$ curves, one observes a faster light activation. A similar increase of $\mathrm{J}_{\mathrm{sc}}$ and $\mathrm{FF}$ is shown after $7 \mathrm{~min}$ of light activation to reach maximum output values $\mathrm{V}_{\mathrm{oc}}, \mathrm{J}_{\mathrm{sc}}, \mathrm{FF}$ and PCE of $0.53 \mathrm{~V}, 10.4 \mathrm{~mA} \mathrm{~cm}^{-2}$, 0.63 and $3.5 \%$, respectively.

In order to quantify the activation phenomenon, a rising time $\left(\mathrm{t}_{10-90}\right)$ for the different PV parameters $\left(\mathrm{J}_{\mathrm{sc}}, \mathrm{V}_{\mathrm{oc}}, \mathrm{FF}\right.$ and PCE) was defined as the time needed for the value to increase from $10 \%$ to $90 \%$ of its maximum. Figure 2 presents the evolution of $\mathrm{t}_{10-90}$ for $\mathrm{J}_{\mathrm{sc}}, \mathrm{V}_{\mathrm{oc}}, \mathrm{FF}$, and PCE as a function of the baking temperature of the $\mathrm{TiO}_{\mathrm{x}}$ layer. These results clearly show that $\mathrm{V}_{\mathrm{oc}}$ reaches its maximum value after the first few seconds independently of the $\mathrm{TiO}_{\mathrm{x}}$ baking time. This apparent Voc rising time is due to the fact that it is undetectable at the beginning as the device acts as an insulator. After a few seconds of illumination, the device starts to present a diode characteristic: the $\mathrm{V}_{\mathrm{oc}}$ appears and does not change significantly upon further illumination. This is clearly different to the S-shape phenomenon observed in direct solar cells, in which the appearance of the S-shape anomaly is accompanied with changes in Voc. In those studies, the inflection points are attributed to the presence of interfacial dipoles. ${ }^{16,17}$ Our result suggests that in $\mathrm{TiO}_{\mathrm{x}}$ based devices the activation process is related to a vanishing of the insulating zone in series with the diode.

On the other hand, $\mathrm{J}_{\mathrm{sc}}$ and $\mathrm{FF}$ (and as a consequence PCE) present a rising time dependent on the $\mathrm{TiO}_{x}$ baking temperature. Generally $\mathrm{J}_{\mathrm{sc}}$ rises faster than $\mathrm{FF}$ and both rising times decrease with increasing $\mathrm{TiO}_{\mathrm{x}}$ baking temperature. These rising times are considerably reduced if the $\mathrm{TiO}_{\mathrm{x}}$ layer is pre-baked under an inert atmosphere at high temperatures (160- $\left.180^{\circ} \mathrm{C}\right)$. Table I summarizes the average PV characteristics and their corresponding rising time for the different $\mathrm{TiO}_{\mathrm{x}}$ baking temperature studied.

For all PV characteristics, an increasing $\mathrm{TiO}_{\mathrm{x}}$ baking temperature leads to a shorter rising time. For unbaked devices, the $\mathrm{t}_{10-90}$ of FF is much longer than that of the devices with $\mathrm{TiO}_{\mathrm{x}}$ baked at $180^{\circ} \mathrm{C}, 183 \mathrm{~s}$, and $51 \mathrm{~s}$, respectively. Lilliedal et al. observed a similar effect of the thermal treatment on the activation of $\mathrm{ZnO}$ based OSC: thermal annealing at $105^{\circ} \mathrm{C}$ leads to a less prominent inflection point in the IV. It was suggested that the desorption of molecular oxygen trapped at the surface of $\mathrm{ZnO}$ could occur thermally at $105^{\circ} \mathrm{C} .^{26}$ Our results are in agreement with this previous report and the decrease of the activation time with increasing temperature could be due to a faster desorption of molecular oxygen. This matter will be discussed in the next paragraph in which the deactivation experiments are analyzed.

Devices made with baked $\mathrm{TiO}_{\mathrm{x}}$ layers also present better $\mathrm{PV}$ characteristics which is mainly due to an increase in the short-circuit current. Indeed, while devices with unbaked titanium oxide layers only reach $2.8 \%$, almost all devices made with baked oxide layers present PCE above 3\%. Moreover, it seems that starting from a baking temperature of $100{ }^{\circ} \mathrm{C}$ the devices PCE reach a plateau around $3.5 \%$ within error. AFM images of the different $\mathrm{TiO}_{\mathrm{x}}$ layers were acquired and no relevant differences in the roughness of the surface were found, thus discounting the possible influence of the substrate morphology on the OSC performance.

TABLE I. $\mathrm{J}_{\mathrm{sc}}, \mathrm{V}_{\mathrm{oc}}$, FF and PCE (average values and standard deviation) and their respective $\mathrm{t}_{10-90}$ for OSC devices with $\mathrm{TiO}_{\mathrm{x}}$ unbaked and baked at 80 , 100 , $120,140,160$ and $180^{\circ} \mathrm{C}$ for $10 \mathrm{~min}$.

\begin{tabular}{lcccccccc}
\hline \hline & $\mathrm{T}\left({ }^{\circ} \mathrm{C}\right)$ & $\mathrm{RT}$ & 80 & 100 & 120 & 140 & 160 \\
\hline $\mathbf{J}_{\mathbf{s c}}$ & $\mathrm{mA} \cdot \mathrm{cm}^{-2}$ & $9.1 \pm 0.6$ & $10.2 \pm 0.3$ & $11.0 \pm 1.3$ & $11.8 \pm 0.2$ & $10.9 \pm 0.7$ & $9.7 \pm 0.2$ & $10.6 \pm 0.3$ \\
& $t_{10-90}(s)$ & 44 & 28 & 22 & 21 & 22 & 17 & 512 \\
$\mathbf{V}_{\text {oc }}$ & $\mathrm{mV}$ & $515 \pm 5$ & $513 \pm 5$ & $519 \pm 4$ & $520 \pm 5$ & $519 \pm 6$ & $515 \pm 5$ & $522 \pm 5$ \\
& $t_{10-90}(s)$ & 8 & 7 & 5 & 8 & 6 & 3 \\
$\mathbf{F F}$ & Value & $0.59 \pm 0.02$ & $0.61 \pm 0.02$ & $0.62 \pm 0.01$ & $0.58 \pm 0.02$ & $0.60 \pm 0.02$ & $0.59 \pm 0.01$ & $0.61 \pm 0.01$ \\
& $t_{10-90}(s)$ & 183 & 91 & 81 & 72 & 78 & 60 & 51 \\
$\mathbf{P C E}$ & $\%$ & $2.8 \pm 0.3$ & $3.2 \pm 0.2$ & $3.6 \pm 0.5$ & $3.6 \pm 0.2$ & $3.4 \pm 0.3$ & $2.9 \pm 0.1$ & $3.4 \pm 0.1$ \\
& $t_{10-90}(s)$ & 144 & 73 & 64 & 64 & 67 & 49 \\
\hline \hline
\end{tabular}


To conclude, a $\mathrm{TiO}_{\mathrm{x}}$-based OSC needs to be activated in order to give its optimal power conversion efficiency. This result indicates that traps are present in the titanium oxide layer or at the interface and that illumination of the $\mathrm{TiO}_{\mathrm{x}}$ layer leads to the elimination or the filling of these traps. Interestingly, our study shows that increasing the annealing temperature of the $\mathrm{TiO}_{\mathrm{x}}$ layer under an inert atmosphere leads to a lower activation time and improved PV characteristics. The next paragraphs focus on the origin of these traps and the influence of baking temperature on conductivity of the $\mathrm{TiO}_{\mathrm{x}}$ layer.

\section{B. Deactivation phenomenon}

As the origin of the traps in $\mathrm{TiOx}$ is still under debate: adsorbed $\mathrm{O}_{2},{ }^{21,27}$ shallow traps,${ }^{20}$ polarization, ${ }^{19}$ the deactivation behavior of the activated OSC has been studied under different conditions. In this experiment, fully activated organic solar cells with unbaked $\mathrm{TiO}_{\mathrm{x}}$ layers were kept under three different storage conditions in the dark: under an inert atmosphere at room temperature $\left(\mathrm{N}_{2}-\mathrm{RT}\right)$, under an inert atmosphere at $80^{\circ} \mathrm{C}\left(\mathrm{N}_{2}-80^{\circ} \mathrm{C}\right)$ and under air at room temperature (Air - RT). Unbaked $\mathrm{TiO}_{\mathrm{x}}$ based OSC were chosen for this study because of their extended activation time. The remaining activation rate (RAR) for each storage time is determined as the ratio between the PCE at $t=0$ (first seconds of illumination) and the maximum PCE. Figure 3 shows the RAR as a function of the storage time under these different conditions. These results clearly show that the deactivation phenomenon is thermally dependent. Indeed, deactivation is the fastest when the device is stored at $80^{\circ} \mathrm{C}$ under an inert atmosphere while an identical device, stored at room temperature and under the same inert atmosphere, does not deactivate, even after $100 \mathrm{~h}$ of storage. We emphasize that the same sample was submitted to successive activation/ deactivation processes and that, for samples stored under inert atmosphere $\left(\mathrm{N}_{2}-\mathrm{RT}\right.$ and $\left.\mathrm{N}_{2}-80^{\circ} \mathrm{C}\right)$, the whole study was carried out continuously under inert atmosphere, i.e., the samples were never in contact with the atmosphere. These

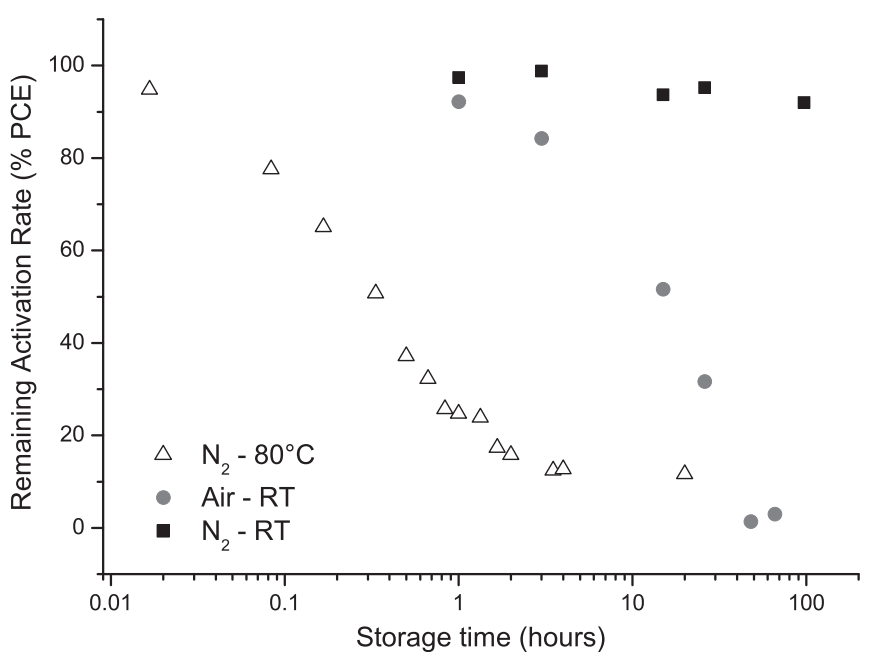

FIG. 3. Remaining Activation Rate as the function of the storage time under $\mathrm{N}_{2}$ at room temperature (black squares), air at room temperature (grey circles) and $\mathrm{N}_{2}$ at $80^{\circ} \mathrm{C}$ (white triangles). results prove that no irreversible physico-chemical modification of the materials or interfaces, such as sol-gel conversion completion or residual solvent removing for instance, is responsible for the activation phenomenon. It also rules out the intervention of $\mathrm{O}_{2}$ as a trap, as suggested by Schmidt et al. and commonly accepted in $\mathrm{ZnO}$ based devices. Indeed, the activation/deactivation phenomenon at $80^{\circ} \mathrm{C}$ and under an inert atmosphere is totally reversible. If $\mathrm{O}_{2}$ is desorbed during the first activation cycle, it is unlikely that the oxygen molecules are re-adsorbed by treating the cell at $80^{\circ} \mathrm{C}$, especially under an inert atmosphere. Eisgruber $e t$ al. reported Sshape distortion in $\mathrm{CuInSe}_{2}$ (CIS) solar cells which can only be removed by blue-light illumination, i.e., by photons with energy greater than the band-gap of $\mathrm{CdS}^{31} \mathrm{~A}$ model was proposed describing a high concentration of deep levels in the CdS window layer and a low concentration of free charge carriers. They also observed a long relaxation time due to a slow discharge rate of the deep states. Their observations and analysis are very similar to that observed in our study (white-light activation, slow deactivation at room temperature storage), suggesting that a similar process might occur in $\mathrm{TiO}_{\mathrm{x}}$ based OSC. It is plausible that the amorphous $\mathrm{TiO}_{\mathrm{x}}$ layer formed via sol-gel procedure contains deep electronic traps in the bandgap of TiOx. Irradiation in the UV range of the TiOx layer induces the direct excitation of valence band electrons into the conduction band. Both electrons and holes will then fill the traps. When the traps are totally filled, the free electron density in the conduction band is increased, the S-shape distortion disappears and the device presents its full performances. One may also note that storage under air at room temperature also provokes the deactivation of the device, even though it is at a different time scale. One might suggest that $\mathrm{O}_{2}$ is adsorbed at the surface of the TiOx and would harvest an electron to formed $\mathrm{O}_{2}{ }^{-}$, therefore emptying traps.

Szczepankiewicz et $a .^{32}$ did an extensive study on the nature of the traps in $\mathrm{TiO}_{2}$ layer. It was shown that, after irradiation of the $\mathrm{TiO}_{2}$ layer and the creation of electron/hole pairs, both charges can be trapped by hydrated surfaces functionalities of $\mathrm{TiO}_{2}$ according to the following mechanisms ${ }^{32,33}$ :

$$
\begin{gathered}
\mathrm{h}_{\mathrm{vb}}{ }^{+}+>\mathrm{Ti}^{\mathrm{IV}} \mathrm{OH} \rightarrow\left\{>\mathrm{Ti}^{\mathrm{IV}} \mathrm{OH} \cdot\right\}^{+}, \\
\mathrm{e}_{\mathrm{cb}}{ }^{-}+>\mathrm{Ti}^{\mathrm{IV}} \mathrm{OH} \rightarrow\left\{>\mathrm{Ti}^{\mathrm{III}} \mathrm{OH}\right\},
\end{gathered}
$$

where $>\mathrm{Ti}^{\mathrm{IV}} \mathrm{OH}$ represents the primary hydrated surface functionality of $\mathrm{TiO}_{2}, \mathrm{e}_{\mathrm{cb}}$ is the conduction band electron, $\mathrm{h}_{\mathrm{vb}}$ is the valence band hole, $\left\{>\mathrm{Ti}^{\mathrm{IV}} \mathrm{OH} \bullet\right\}^{+}$is the surface trapped valence band hole and $\left\{>\mathrm{Ti}^{\mathrm{III}} \mathrm{OH}\right\}$ is the surface trapped conduction band electron. These species are stable over time under different storage conditions. The trapped electrons in $\left\{>\mathrm{Ti}^{\mathrm{III}} \mathrm{OH}\right\}$ species are only released upon illumination under $\mathrm{O}_{2}$ and $\mathrm{H}_{2} \mathrm{O}$. Strong electron acceptor moieties such as $\mathrm{Br}_{2}$ lead also to de-trapping while only $\mathrm{O}_{2}$ does not. Although in the Szczepankiewicz et al. paper, $\mathrm{TiO}_{2}$ was studied in a crystalline form, some similarities with our study can be observed. Actually, our results highlight the high stability of the trapped charges under inert atmosphere at room temperature. Even storage in air (in presence of $\mathrm{O}_{2}$ and $\mathrm{H}_{2} \mathrm{O}$ ) 
does not lead to a fast de-activation process, as shown by Szczepankiewicz et al. Based on the correlations between the two studies, one could suggest that the nature of the traps present in our devices are those resulting from reaction (1) and/or (2). In our study, $\mathrm{TiO}_{\mathrm{x}}$ layer is amorphous. The trap density is thus higher than in a single crystal and $\mathrm{Ti}^{\mathrm{IV}} \mathrm{OH}$ species might exist in the bulk and not only at the surface as it is the case for crystalline $\mathrm{TiO}_{2}$. A basic storage in air is then less efficient to de-activate because either $\mathrm{O}_{2}$ or $\mathrm{H}_{2} \mathrm{O}$ have to diffuse in the bulk to release the charges in the traps. Further experiments will need to be performed in order to identify clearly the nature of the traps and quantify them.

\section{Pure TiOx based devices}

In order to investigate in detail the $\mathrm{TiO}_{\mathrm{x}}$ activation phenomenon and the influence of baking the $\mathrm{TiO}_{\mathrm{x}}$ under an inert atmosphere, $\mathrm{TiO}_{\mathrm{x}}$ layers with aluminum contacts were fabricated with the architecture presented in the inset of Figure 4. Before the deposition of the aluminum contacts, the $\mathrm{TiO}_{\mathrm{x}}$ layers were exposed to different baking temperatures under an inert atmosphere, from $80^{\circ} \mathrm{C}$ to $180^{\circ} \mathrm{C}$ in order to study its influence on the photoconduction of the $\mathrm{TiO}_{\mathrm{x}}$ layers. The evolution of $\mathrm{I}(\mathrm{V})$ characteristics of unbaked and baked $\left(80^{\circ} \mathrm{C}\right.$ to $\left.180^{\circ} \mathrm{C}\right)$ devices under illumination $(100 \mathrm{~mW}$ $\mathrm{cm}^{-2}$, AM $1.5 \mathrm{G}$, inert atmosphere) was investigated and the evolution of the conductance at a bias voltage of $1 \mathrm{~V}$ is plotted in Figure 4. It is clear that $\mathrm{TiO}_{\mathrm{x}}$ devices have very low conductivity prior illumination. Conductance below $10^{-11} \mathrm{~S}$ is found in all cases before illumination, while it reaches up to $4 \times 10^{-9} \mathrm{~S}$ after $9 \mathrm{~min}$ of illumination. Such a behavior had already been reported in a few articles on $\mathrm{TiO}_{\mathrm{x}}$-only devices. ${ }^{34,35}$ Pomoni et al. ${ }^{35}$ attributed the increase in the $\mathrm{TiO}_{\mathrm{x}}$ photoconductivity upon illumination to traps filling until most of the traps are filled and the maximum photoconductivity is reached. In our experiments, the photoconductivity of baked and unbaked $\mathrm{TiO}_{\mathrm{x}}$ layers increases similarly upon illumination; however, the activation rate and the maximum conductivity reached are influenced by the thermal

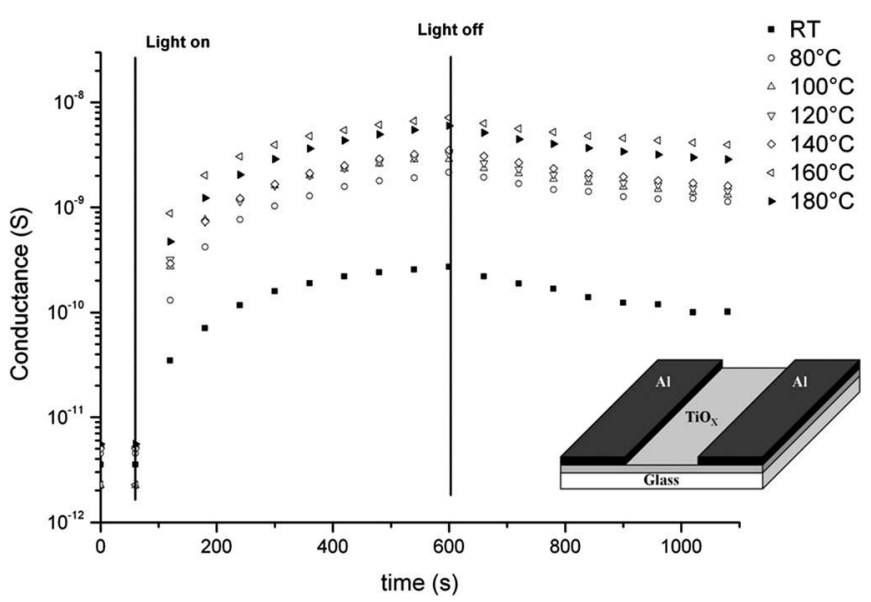

FIG. 4. Evolution of the conductance at a bias voltage of $1 \mathrm{~V}$ upon illumination for unbaked TiOx $(\square)$ and TiOx baked at $80^{\circ} \mathrm{C}(\bigcirc), 100^{\circ} \mathrm{C}(\Delta), 120^{\circ} \mathrm{C}$ $\left.(\nabla), 140^{\circ} \mathrm{C} \triangleleft\right), 160^{\circ} \mathrm{C}(\triangleright)$ or $180^{\circ} \mathrm{C}(\bullet)$. Inset: Architecture of the $\mathrm{TiO}_{\mathrm{x}}$ devices for the study of the activation phenomenon treatment. For instance, baked $\mathrm{TiO}_{\mathrm{x}}$ layers reach a higher photoconductivity than the unbaked device.

The first observation is that light-activated baked $\mathrm{TiO}_{\mathrm{x}}$, even at low temperature such as $80^{\circ} \mathrm{C}$, present much higher conductivity than activated unbaked devices: there is at least one order of magnitude difference in the conductance. In addition, the higher the baking temperature, the better is the photoconductivity under illumination. Indeed, after the same illumination time, one can observe that the current increases gradually with the baking temperature, except for high temperature around $160-180^{\circ} \mathrm{C}$. Based on the hypothesis of Pomoni et al. ${ }^{35}$ one could suggest that the increase of the $\mathrm{TiO}_{\mathrm{x}}$ baking temperature leads to the diminution of the trap density (primary hydrated surface functionality of $\mathrm{TiO}_{2}$ ), and, therefore, to a faster attainment of high conductance values. Pomoni et al. also showed that the maximum photoconductivity reached is lower when the trap density is higher (in their case adsorbed $\mathrm{O}_{2}$ ). This hypothesis is in agreement with the increase of the maximum conductivity with increasing baking temperature, i.e., decreasing trap density.

The second observation is that a persistent photoconductivity occurs. This phenomenon is a light-induced change in the free carrier concentration which persists once the light excitation is removed. This phenomenon has already been observed in $\mathrm{GaN},{ }^{36,37} \mathrm{TiO}_{2}{ }^{38}$ and $\mathrm{ZnO}^{23}$ No systematic investigation has been made in this paper to explain the exact origin of the persistent photoconductivity. However, this behavior could be another signature of charges trapped in deep levels which are responsible of the light-activation phenomenon observed in inverted solar cells. A metastable state is activated with UV light in the $\mathrm{TiO}_{\mathrm{x}}$ layer which acts as doping and reduces the series resistance of the inverted solar cell.

These changes in $\mathrm{TiO}_{x}$ conductivities can be linked to the differences observed in the OPV devices. Power conversion efficiencies vary from $2.8 \%$ for unbaked devices to more than $3 \%$ for devices with baked $\mathrm{TiO}_{\mathrm{x}}$. This increase can be explained by the better conductivity of baked $\mathrm{TiO}_{\mathrm{x}}$ layers which would result in a lower series resistance, as observed in Figure 1. However, no obvious discrepancy is noticeable on the OSC photovoltaic characteristics versus the gradual increase of the $\mathrm{TiO}_{x}$ conductivity. Indeed, Table I indicates that devices with $\mathrm{TiO}_{\mathrm{x}}$ baked at $100{ }^{\circ} \mathrm{C}$ present already very good PV characteristics. One can suggest that, above a specific conductivity of the $\mathrm{TiO}_{\mathrm{x}}$ layer, other factors are limiting the PCE and the further increase of the $\mathrm{TiO}_{\mathrm{x}}$ conductivity would have no influence on the PV characteristics, especially for thin $\mathrm{TiO}_{\mathrm{x}}$ layers. ${ }^{34}$

From these results, it is also possible to understand the relation between the $\mathrm{TiO}_{\mathrm{x}}$ baking temperature and the activation time. Data presented in Table I suggest that the conductivity of $\mathrm{TiO}_{\mathrm{x}}$ layers baked at $100^{\circ} \mathrm{C}$ is sufficient for the OSC to reach high performances and that the device presents $90 \%$ of its maximum PCE after $64 \mathrm{~s}$ of illumination. Figure 4 shows that after 1 min of illumination, the conductance of the $\mathrm{TiO}_{\mathrm{x}}$ device under a $1 \mathrm{~V}$ bias is $2.7 \times 10^{-10} \mathrm{~S}$. The unbaked device reaches this value after more than $10 \mathrm{~min}$ of illumination while the device made with $\mathrm{TiO}_{\mathrm{x}}$ baked at $80^{\circ} \mathrm{C}$ reaches it between 2 and 3 min. For devices with $\mathrm{TiO}_{x}$ baked 
at higher temperature, this value is reached in less than $1 \mathrm{~min}$. As a conclusion, the higher the $\mathrm{TiO}_{\mathrm{x}}$ baking temperature, the faster the $\mathrm{TiO}_{\mathrm{x}}$ reaches the necessary conductivity and the faster the OSC device reaches its maximum performance.

\section{CONCLUSIONS}

Thermal annealing under an inert atmosphere of $\mathrm{TiO}_{\mathrm{x}}$ layer prior to active layer deposition is shown to shorten the activation period and to improve the overall performances of the devices. The baking process improves the conductivity of the $\mathrm{TiO}_{\mathrm{x}}$ layer and explains the gain in performances and reduction of the activation time. Deactivation experiments were performed in order to understand the origin of the activation phenomenon. It was shown that activation/deactivation was fully reversible under an inert atmosphere and that deactivation was thermally assisted. The activation phenomenon is attributed to the presence of traps localized on the primary hydrated surface functionalities of $\mathrm{TiO}_{\mathrm{x}}$ which have to be filled before the oxide reaches a sufficient conductivity, rather than desorption of $\mathrm{O}_{2}$. Storage of the device under air leads to a slow deactivation of the OSC. One can suggest that adsorbed oxygen can empty the traps by creating $\mathrm{O}_{2}{ }^{-}$ species. An optimal baking temperature of the $\mathrm{TiO}_{\mathrm{x}}$ layer was found at $120^{\circ} \mathrm{C}$. In this case, OSC present a reasonable short activation time of approximately $1 \mathrm{~min}$ and an average PCE of $3.58 \%$ (a maximum PCE of $4 \%$ ).

\section{ACKNOWLEDGMENTS}

This work has been supported by the French CNRS, the Région Aquitaine and the ANR through the ANR-10-HABISOL-003 «CEPHORCAS» project. The RHODIA Company (part of SOLVAY Group) is acknowledged for supporting part of the post-doctoral fellowship of Dr. Sylvain Chambon in our group. Finally, authors gratefully thank Sokha Khiev for his technical contribution to this work and Steven Meeker for his help to improve the language quality.

${ }^{1}$ G. Dennler, M. C. Scharber, and C. J. Brabec, Adv. Mater. 21, 1323 (2009).

${ }^{2}$ Y. Sahin, S. Alem, R. de Bettignies, and J.-M. Nunzi, Thin Solid Films 476, 340 (2005).

${ }^{3}$ G. Li, C. W. Chu, V. Shrotriya, J. Huang, and Y. Yang, Appl. Phys. Lett. 88, 253503 (2006).

${ }^{4}$ M. S. White, D. C. Olson, S. E. Shaheen, N. Kopidakis, and D. S. Ginley, Appl. Phys. Lett. 89, 143517 (2006).

${ }^{5}$ F. Zhang, X. Xu, W. Tang, J. Zhang, Z. Zhuo, J. Wang, J. Wang, Z. Xu, and Y. Wang, Sol. Energy Mater. Sol. Cells 95, 1785 (2011).
${ }^{6}$ J. B. Kim, C. S. Kim, Y. S. Kim, and Y.-L. Loo, Appl. Phys. Lett. 95, 183301 (2009).

${ }^{7}$ F. J. Zhang, D. W. Zhao, Z. L. Zhuo, H. Wang, Z. Xu, and Y. S. Wang, Sol. Energy Mater. Sol. Cells 94, 2416 (2010).

${ }^{8}$ C. Y. Jiang, X. W. Sun, D. W. Zhao, A. K. K. Kyaw, and Y. N. Li, Sol. Energy Mater. Sol. Cells 94, 1618 (2010).

${ }^{9}$ H. Oh, J. Krantz, I. Litzov, T. Stubhan, L. Pinna, and C. J. Brabec, Sol. Energy Mater. Sol. Cells 95, 2194 (2011).

${ }^{10}$ R. Steim, S. A. Choulis, P. Schilinsky, and C. J. Brabec, Appl. Phys. Lett. 92, 093303 (2008).

${ }^{11}$ P. de Bruyn, D. J. D. Moet, and P. W. M. Blom, Org. Electron. 11, 1419 (2010).

${ }^{12}$ F. C. Krebs, Sol. Energy Mater. Sol. Cells 92, 715 (2008).

${ }^{13}$ N. Sekine, C.-H. Chou, W. L. Kwan, and Y. Yang, Org. Electron. 10, 1473 (2009).

${ }^{14}$ Z. Xu, L.-M. Chen, G. Yang, C.-H. Huang, J. Hou, Y. Wu, G. Li, C.-S. Hsu, and Y. Yang, Adv. Funct. Mater. 19, 1227 (2009).

${ }^{15}$ H.-H. Liao, L.-M. Chen, Z. Xu, G. Li, and Y. Yang, Appl. Phys. Lett. 92, 173303 (2008).

${ }^{16}$ A. Kumar, S. Sista, and Y. Yang, J. Appl. Phys. 105, 094512 (2009).

${ }^{17}$ A. Wagenpfahl, D. Rauh, M. Binder, C. Deibel, and V. Dyakonov, Phys. Rev. B 82, 115306 (2010).

${ }^{18}$ T. Kuwabara, T. Nakayama, K. Uozumi, T. Yamaguchi, and K. Takahashi, Sol. Energy Mater. Sol. Cells 92, 1476 (2008).

${ }^{19}$ T. Kuwabara, C. Iwata, T. Yamaguchi, and K. Takahashi, ACS Appl. Mater. Interfaces 2, 2254 (2010).

${ }^{20}$ C. S. Kim, S. S. Lee, E. D. Gomez, J. B. Kim, and Y.-L. Loo, Appl. Phys. Lett. 94, 113302 (2009).

${ }^{21}$ H. Schmidt, K. Zilberberg, S. Schmale, H. Flugge, T. Riedl, and W. Kowalsky, Appl. Phys. Lett. 96, 243305 (2010).

${ }^{22}$ Y. Jin, J. Wang, B. Sun, J. C. Blakesley, and N. C. Greenham, Nano Lett. 8, 1649 (2008).

${ }^{23}$ F. Verbakel, S. C. J. Meskers, and R. A. J. Janssen, Appl. Phys. Lett. 89, 102103 (2006).

${ }^{24}$ G. Lakhwani, R. F. H. Roijmans, A. J. Kronemeijer, J. Gilot, R. A. J. Janssen, and S. C. J. Meskers, J. Phys. Chem. C 114, 14804 (2010).

${ }^{25}$ A. Manor, E. A. Katz, T. Tromholt, and F. C. Krebs, Sol. Energy Mater. Sol. Cells 98, 491 (2012).

${ }^{26}$ M. R. Lilliedal, A. J. Medford, M. V. Madsen, K. Norrman, and F. C. Krebs, Sol. Energy Mater. Sol. Cells 94, 2018 (2010).

${ }^{27}$ N. Golego, S. A. Studenikin, and M. Cocivera, Phys. Rev. B 61, 8262 (2000).

${ }^{28}$ M. T. Dang, L. Hirsch, and G. Wantz, Adv. Mater. 23, 3597 (2011).

${ }^{29}$ M. Burgos and M. Langlet, J. Sol-Gel Sci. Technol. 16, 267 (1999).

${ }^{30} \mathrm{G}$. Li, Y. Yao, H. Yang, V. Shrotriya, G. Yang, and Y. Yang, Adv. Funct. Mater. 17, 1636 (2007).

${ }^{31}$ I. L. Eisgruber, J. E. Granata, J. R. Sites, J. Hou, and J. Kessler, Sol. Energy Mater. Sol. Cells 53, 367 (1998).

${ }^{32}$ S. H. Szczepankiewicz, A. J. Colussi, and M. R. Hoffmann, J. Phys. Chem. B 104, 9842 (2000).

${ }^{33}$ M. R. Hoffmann, S. T. Martin, W. Choi, and D. W. Bahnemann, Chem. Rev. 95, 69 (1995).

${ }^{34}$ M. Takahashi, K. Tsukigi, T. Uchino, and T. Yoko, Thin Solid Films 388, 231 (2001).

${ }^{35}$ K. Pomoni, A. Vomvas, and C. Trapalis, Thin Solid Films 479, 160 (2005).

${ }^{36}$ C. H. Qiu and J. I. Pankove, Appl. Phys. Lett. 70, 1983 (1997).

${ }^{37}$ M. T. Hirsch, J. A. Wolk, W. Walukiewicz, and E. E. Haller, Appl. Phys. Lett. 71, 1098 (1997).

${ }^{38}$ C. Itoh and A. Wada, Phys. Status Solidi C 2, 629 (2005). 